\title{
PENGEMBANGAN MODEL DESENTRALISASI ASIMETRIS KAWASAN PERKOTAAN (STUDI DI KABUPATEN INDRAMAYU PROVINSI JAWA BARAT)
}

\author{
Rinny Dewi Anggraeni \\ Institut Pemerintahan Dalam Negeri \\ Rinny.anggraeni@yahoo.co.id \\ Aradea Mochammad Akbar Maulana \\ Universitas Maranatha \\ fshow48@gmail.com
}

DOI: http://dx.doi.org/10.23969/decision.v1i2.1840

\begin{abstract}
Currently, Indramayu regency in its capacity becomes a strategic area of West Java province, that is a center of trade and strategic meeting of two regions, namely Sumedang and Kuningan regency. Indramayu, that was once characterized as an agrarian area, nowadays transformed into an urban area. Therefore, in this decentralization policy, it should be directed to become a study of policies that can accommodate a variety of different characteristics and conditions of each region. The implementation of this different treatments is known as asymmetric decentralization. The study of the development of asymmetric decentralization in Indonesia, especially in Indramayu regency is: how the existing condition of the implementation of asymmetric decentralization policy in Indramayu district; and how the asymmetric decentralization model in Indramayu as an urban area which can be used as an alternative to minimize center-periphery relations, as well as to boost the competitiveness of the region in an effort to accelerate the achievement of welfare. In accordance with the principle of a qualitative approach, the choices of interviewees in this research are not taken from the population, but they are taken purposely, and open the possibility to search the interviewees in snowballing way. The interviewees (informants) have been selected according to considerations of expertise, positions / official positions that relate to the issue (policy makers, implementer of bureaucracy), and also parties that relate to the issues / interests of the theme and the object of the research. More specifically, the interviewees are academics / experts in other areas of government, community leaders / NGOs working on the issue in Indramayu regency, local government of West Java Province, local government of Indramayu regency and ranks of the official concerned, the local council (DPRD) elements of West Java province and Indramayu regency, and others that related to the problems examined. The research shows that the Development of Asymmetric Decentralization Model in Indramayu must meet the following criteria: (1) the rationalization of authority, which means that there should be many strong local government institutions, which each of them has the constitutional authority or rule of government; (2) the differentiation of structure, which means that within the body of each authority of local government institutions has the quality and scope of authority which not compete, claiming, and remove the responsibility to each other; (3) the expand of community political communication participation or rule of law instrument in the administration of local government powers. In this case, the community political role in actively and critically to the philosophical foundation of democratic government, namely: accountability, participation, agreement, equal rights, checks and balances. In applying the asymmetric decentralization model, as in Indramayu, there should be a difference of treatment between one region to another region by considering the potential diversity of the region. This thing will help to mobilize local resources and government resources which are more efficient to improve the communities in the region. Therefore, the essence of decentralization and local autonomy that built in Indonesia after the reform era implement the kinds of autonomy that exist in Indonesia (regular and
\end{abstract}


special autonomy) that becomes empirical evidence that can be used as the basis for the adoption of the concept of asymmetric decentralization.

\title{
Keywords: The development study, asymmetric decentralization
}

\begin{abstract}
Abstrak
Kabupaten Indramayu dalam kedudukannya sebagai Kawasan Strategis Provinsi Jawa Barat sebagai pusat perdagangan dan pertemuan stategis dua kawasan, yaitu Kabupaten Sumedang dan Kabupaten Kuningan kawasan Indramayu yang dulunya bercirikan agraris berubah menjadi kawasan perkotaan. Dalam kebijakan desentralisasi ini perlu diarahkan menjadi kajian berupa kebijakan yang dapat mengakomodasikan berbagai perbedaan karakteristik serta kondisi masingmasing daerah. Pemberlakuan (treatment) berbeda ini dikenal dengan sebutan desentralisasi asimetris (asymmetric decentralization). Kajian pengembangan desentralisasi asimetris di Indonesia, terutama di Kabupaten Indramayu, yaitu: bagaimana kondisi eksisting penyelenggaraan kebijakan desentralisasi asimetris di kabupaten Indramayu; dan bagaimana model desentralisasi asimetris di Indramayu sebagai kawasan perkotaan yang dapat dijadikan alternatif meminimalisasikan hubungan pusat-daerah, sekaligus dapat mendorong peningakatan daya saing daerah dalam upaya percepatan pencapaian kesejahteraan masyarakatnya. Sesuai dengan prinsip pendekatan kualitatif, pilihan narasumber penelitian ini tidak ditarik dari populasi melainkan secara purposif, dan membuka kemungkinan melakukan penelusuran narasumber secara snowbolling. Para narasumber (informan) dipilih menurut pertimbangan keahlian, memiliki kedudukan/jabatan resmi terkait masalah (pembuat kebijakan, pelaksana birokrasi), serta para pihak yang mempunyai keterkaitan masalah/ kepentingan dengan tema dan obyek penelitian. Lebih jelasnya, narasumber yang diwawancari adalah kalangan akademisi/pakar bidang pemerintahan lainnya, tokoh masyarakat/ LSM yang bergerak dalam masalah di Kabupaten Indramayu, Pemda Provinsi Jawa Barat, Pemda Kabupaten Indramayu maupun jajaran pejabat terkait, unsur DPRD Provinsi Jawa Barat dan Kabupaten Indramayu, dan lain-lain yang terkait dengan masalah yang diteliti. Hasil Penelitian menunjukkan bahwa Pengembangan Model Desentralisasi Asimetris di Kabupaten Indramayu harus memenuhi kriteria sebagai berikut: (1) adanya rasionalisasi kewenangan, artinya banyak berdiri kokoh kelembagaan pemerintah daerah yang masing-masing memiliki wewenang secara konstitusional atau rule of government; (2) adanya deferensiasi struktur, maksudnya didalam tubuh setiap kewenangan kelembagaan pemerintah daerah terdapat bobot dan ruang lingkup otoritas yang tidak saling sikut, saling klaim, dan saling lempar tanggung jawab; (3) adanya perluasan peran serta komunikasi politik massa atau rule of law instrument dalam penyelenggaraan kekuasaan pemerintah daerah. Dalam hal ini peran politik massa secara aktif dan kritis terhadap landasan filosofis pemerintahan demokratis, yaitu: adanya akuntabilitas, partisipatif, kesepakatan, kesetaraan hak, check and ballance. Dalam penerapan model desentralisasi asimetris ini, seperti di Kabupaten Indramayu, sebaiknya ada perbedaan perlakuan (treatment) antara satu daerah dan daerah yang lain dengan mempertimbangkan keragaman potensi daerah. Hal ini akan membantu proses mobilisasi sumber daya daerah dan sumber daya pemerintah yang lebih efisien untuk meningkatkan masyarakat di daerah. Oleh karena, esensi desentralisasi dan otonomi daerah yang dibangun di Indonesia pasca reformasi diterapkan jenis-jenis otonomi yang ada di Indonesia (otonomi reguler dan otonomi khusus) yang menjadi bukti empiris yang bisa dijadikan dasar untuk pengadopsian konsep desentralisasi asimetris.
\end{abstract}

Kata Kunci: pengembangan, desentralisasi asimetris

\section{PENDAHULUAN}

Latar Belakang Penelitian

Kabupaten Indramayu

kedudukannya sebagai Kawasan

Strategis Provinsi Jawa Barat sebagai pusat perdagangan dan pertemuan stategis dua kawasan, yaitu Kabupaten 
Sumedang dan Kabupaten Kuningan ${ }^{1}$, kawasan Indramayu yang dulunya bercirikan agraris berubah menjadi kawasan perkotaan. Menurut Studi Kelayakan Kawasan Indramayu sebagai Kawasan Perkotaan yang dilakukan oleh Bappeda Kabupaten Indramayu tahun 2009, kawasan ini sudah bercirikan kawasan perkotaan, walaupun agar dapat berkembang menjadi kota yang layak huni, nyaman dan berkelanjutan membutuhkan beberapa persyaratan yang menjadi prioritas untuk dipenuhi terutama yang terkait dengan aspek pelayanan perkotaan (prasarana perkotaan $)^{2}$.

Kawasan Kabupaten Indramayu kini berkembang sangat pesat, namun harus diakui bahwa pembangunan fisik dan perekonomian yang sudah berkembang pesat tidak berbanding lurus dengan penyediaan berbagai pelayanan publik sebagai kawasan perdagangan dan perkotaan. Menurut Baldan (2007) bahwa kawasan Indramayu belum berkembang sebagai mestinya, pasalnya jika melihat keadaan yang ada di Kabupaten Indramayu belum mencapai gambaran ideal sebuah kawasan perdagangan dan perkotaan ${ }^{3}$. Belum

\footnotetext{
${ }^{1}$ Dalam konteks penataan ruang, Peraturan daerah Provinsi Jawa Barat Nomor 22 tahun 2010 tentang Rencana Tata Ruang Wilayah Provinsi Jawa Barat Tahun 2009 - 2029, menetapkan Kawasan Jatinangor sebagai Kawasan Strategis Provinsi sebagai pusat pendidikan, dan juga termasuk wilayah Kawasan Perkotaan Cekungan Bandung. Ada lima kecamatan yang termasuk kawasan ini, yaitu : Kecamatan Jatinangor, Kecamatan Cimanggung, Kecamatan Tanjungsari, Kecamatan Sukasari dan Kecamatan Pamulihan.
}

2 -----. 2009. Studi Kelayakan Kawasan Jatinangor Sebagai Kawasan Perkotaan. Laporan Penelitian, Badan Perencanaan Pembangunan Daerah. Sumedang : Pemerintah Kabupaten Sumedang.

${ }^{3}$ Orasi Ilmiah Ferry Mursyidan Baldan, Menteri Agraria dan Tata Ruang/Kepala Badan Pertanahan Nasional, 2015, pada Dies Natalis ke- tercapainya gambaran ideal Indramayu juga disebabkan belum adanya komitmen kerjasama untuk mewujudkan kawasan perdagangan tersebut di antaranya kerjasama dengan Kabupaten Sumedang dan Kabupaten Kuningan. Kerja sama tersebut dilakukan untuk membangun kohesi sosial di kawasan Indramayu.

Kekhususan kawasan Kabupaten Indramayu oleh pemerintah daerah harus membentuk payung hukum kebijakan yang berbeda dengan kebijakan reguler lainnya. Perlakuan khusus harus bisa diterapkan di kawasan ini, seperti pelarangan penjualan lahan kepada masyarakat di luar Kabupaten Indramayu atau pihak di luar sektor perdagangan. Atmosfer perkotaan pun harus terbangun, seperti penyediaan berbagai fasilitas yang menunjangnya. Sehingga dengan kebijakan khusus tersebut, pemerintah mempunyai peran dalam mengontrol penggunaan lahan di Kabupaten Indramayu sebagai perwujudan kawasan perdagangan dan perkotaan.

Dalam kedudukannya sebagai kawasan perkotaan khusus, substansi kekhususan Kabupaten Indramayu terlihat menonjol pada penyelenggaran pemerintahan di level desa dan supra desa, implikasinya pada kekhususan penerapan pelayanan tugas-tugas pemerintahan yang berbeda dengan daerah di luar kawasan. Kondisi saat ini keberadaan desa-desa otonom di kawasan ini, terbatas (tidak) memiliki kewenangan yang cukup untuk mengatur wilayahnya secara otonom. Idealnya sebagai desa otonom merupakan kesatuan masyarakat hukum yang memiliki batas wilayah yang berwenang untuk mengatur dan mengurus urusan pemerintahan, kepentingan masyarakat setempat berdasarkan prakarsa masyarakat, hak asal usul.

57 FISIP Unpad, bertajuk "Kebijakan Bidang Agraria dalam Penataan Kawasan Pendidikan”. 
Peran kecamatan tidak memiliki kewenangan yang cukup untuk mengatur wilayah ini. Kecamatan saat ini lebih banyak berfungsi untuk menyelenggarakan tugas umum pemerintahan dan pembuatan rekomendasi berbagai pelayanan administratif. Sementara itu, dinas/ badan di lingkungan Pemerintah Kabupaten Indramayu yang memiliki kewenangan untuk mengelola kawasan ini belum melakukan banyak hal dalam menata ruang dan menyiapkan berbagai pelayanan publik yang optimal.

Dengan demikian, pengakuan negara atas keberadaan Kawasan Perkotaan dengan kekhususannya ini membawa konsekuensi perlunya pengaturan secara khusus model pengelolaan Kawasan Perkotaan dipandang dari sudut penyelenggaraan sistem pemerintahan daerah (Tarlton dalam McGarry, 2007).

Dalam pengelolaan kawasan perkotaan seperti Indramayu perlu digulirkan kebijakan dari pemerintah. Adapun tujuan kebijakan desentralisasi menurut Smith (2001) selain untuk mewujudkan good governance, juga dimaksudkan untuk mewujudkan efisiensi, transparansi dan akuntabilitas dalam penyelanggaraan pelayanan publik. Sementara, UNDP (2009) menjelaskan bahwa desain desentralisasi memiliki dua tujuan: ekonomi dan politik. Tujuan ekonomi yang ingin dicapai melalui desentralisasi adalah mewujudkan kesejahteraan masyarakat, sementara tujuan politik desentralisasi adalah mewujudkan demokratisasi pemerintahan daerah melalui pertanggungjawaban langsung kepala daerah kepada konstituen mereka di daerah.

Secara konseptual, perspektif politik desentralisasi (political desentralization perspektive) seperti fokus studi dari Mawhood (1987),
Goldberg (1996), Kingsley (1996), dan Rondinelli (1983) merupakan sumbangan atas perkembangan pemerintahan modern yang bersifat devolutif. Kemudian Mawhood (1987) menambahkan bahwa tujuan utama dari kebijakan desentralisasi adalah sebagai upaya mewujudkan keseimbangan poitik (political equality), akuntabilitas pemerintah lokal (local accountability) dan pertanggungjawaban pemerintah lokal (local responsibility). Ketiga tujuan ini saling berkaitan satu sama lain.

Lebih tegas lagi Mawhood (1987: 14) memberikan karakteristik desentralisasi sebagai: a decentralized local body should have: (1) its own budget, (2) a separate legal existence, (3) authority to allocate substantial resources, (4) a range of different function, and (5) the decisions being made by representative of the local people. Pada hakekatnya konsep otonomi daerah atau desentralisasi mengandung arti kebebasan untuk mengambil keputusan, baik politik maupun administrasi, menurut prakarsa sendiri untuk kepentingan masyarakat setempat dengan tetap menghormati peraturan perundang-undangan nasional.

Kemudian Rondinelli (1983: 93) memberikan makna desntralisasi secara lebih komprehensif sebagai: the transfer or delegation of legal and political authority to plan, make decisions and manage public function from the central government and its agencies to field organizations of those agencies, subordinate units of government, autonomous public corporations, area wide or regional development authorities: functional authorities, autonomous local government, or nongovernmental organizations.

Di sisi lain Lemieux (1988: 34) menjelaskan bahwa otonomi daerah sebagai suatu kekuasaan untuk mengambil keputusan sendiri, baik 
keputusan politik, keputusan administrasi dengan tetap menghormati peraturan perundang-undangan. Jadi, otonomi daerah yang tepat bukan hanya sekadar reorientasi paradigma self local government menjadi self local governance tetapi harus ditindaklanjuti dengan restrukturisasi pelaksanaan otonomi daerah yang sarat dengan nilai kebebasan (liberty), partisipasi (participation), demokrasi (democracy) dan akuntabilitas (accountability) (Kingsley, 1996: 3).

Meskipun desentralisasi seolah terlihat sangat menjanjikan sebagai sebuah pilihan dalam manajemen pemerintahan sebuah negara, namun pada tataran empirik, implementasi kebijakan desentralisasi merupakan pedang bermata dua (Smith, 2001), twoedged of sword, yang dapat menimbulkan dampak positif maupun negatif. Brillantes dalam Widodo (2012) menambahkan bahwa adanya implikasi positif dan negatif ini bukan berarti bahwa kebijakan desentralisasi tidak cocok untuk diterapkan di Indonesia, hanya saja saat ini masih belum optimal. Oleh karena desain desentralisasi di Indonesia merupakan desain tunggal, yang memberikan perlakuan seragam (simetris) kepada setiap daerah otonom yang ada. Hal ini berarti bahwa pengaturan hubungan pusat-daerah dalam aspek kewenangan, kelembagaan, keuangan, dan pengawasan dibuat sama antara daerah satu dengan daerah lainnya. Padahal setiap daerah memiliki karakteristik yang sangat beragam, oleh karena itu penerapan desain tunggal kebijakan desentralisasi ini memang tidak sepenuhnya mampu mengatasi berbagai tantangan. Oleh karena itu selain desentralisasi simetris, dibuat juga model desentralisasi asimetris.

Dalam kebijakan desentralisasi ini perlu diarahkan menjadi kajian berupa kebijakan yang dapat mengakomodasikan berbagai perbedaan karakteristik serta kondisi masing-masing daerah. Adapun pemberlakuan (treatment) berbeda ini dikenal dengan sebutan desentralisasi asimetris (asymmetric decentralization). Kemudian dalam pandangan Charles Tarlton (dalam McGarry, 2007), seorang ilmuwan dari University of California Berkeley, USA yang pertama kali memulai diskusi seputar desentralisasi asimetris, menyatakan bahwa pembeda utama model desentralisasi asimetris terletak pada tingkat kesesuaian (conformity) dan keumuman (commonality) dalam hubungan suatu level pemerintahan (negara/bagian/daerah) dengan sistem pemerintahan secara umum, pemerintah pusat maupun antar negara bagian/daerah dengan pemerintah pusat tersebut yang didasari pada jumlah dan bobot kewenangan yang sama. Sementara dalam model asimetris, ditandai dengan "the level of conformity and commonality in the relation of each separate political unit of the system to both the system as a whole and to the other component units". Ada hubungan simetris antar setiap negara bagian/daerah dengan pemerintah pusat tersebut didasari oleh jumlah dan bobot kewenangan yang sama. Sedangkan dalam pola asimetris, ada satu atau lebit unit pemerintah lokal yang memiliki "possessed of varying degree of autonomy and power".

Pada konteks Indonesia, ruang desentralisasi asimetris sebenarnya telah diterapkan, ditandai dengan berlakunya kebijakan otonomi khusus terhadap beberapa daerah seperti: Aceh, Papua, DKI Jakarta, dan D.I. Jogjakarta, disamping juga memberlakukan otonomi reguler. Tri Widodo (2010) menjelaskan bahwa beberapa bentuk otonomi yang dijalankan secara bersamaan seperti ini sesuangguhnya disebut sebagai desentralisasi asimetris. 
Selain itu, Widodo (2010) menambahkan bahwa penyusunan ulang desentralisasi asimetris ini adalah untuk meningkatkan kesejahteraan masyarakat, bahkan jika ditinjau dari aspek ketergantungan (dependency) daerah pada sumber pembiayaan dari pusat, masih banyak provinsi dan kabupaten/kota yang minim tingkat kemandiriannya, untuk mengelola pembangunan di derahnya. Hal ini berdampak kurang baik pada keberlangsungan (sustainability) pembangunan.

Oleh karena itu, pada penelitian ini penulis berfokus pada kajian pengembangan desentralisasi asimetris di Indonesia, terutama di Kabupaten Indramayu, yaitu: bagaimana kondisi eksisting penyelenggaraan kebijakan desentralisasi asimetris di Kabupaten Indramayu; dan bagaimana model desentralisasi asimetris di Kabupaten Indramayu sebagai kawasan perkotaan yang dapat dijadikan sebagai alternatif meminimalisasi hubungan pusat-daerah, sekaligus dapat mendorong peningkatan daya saing daerah dalam upaya percepatan pencapaian kesejahteraan masyarakatnya.

\section{Identifikasi Masalah}

1. Kabupaten Indramayu dalam kedudukannya sebagai Kawasan Strategis Provinsi Jawa Barat sebagai pusat perdagangan dan pertemuan stategis dua kawasan, yaitu Kabupaten Sumedang dan Kabupaten Kuningan, kawasan Indramayu yang dulunya bercirikan agraris berubah menjadi kawasan perkotaan.

2. Kekhususan kawasan Kabupaten Indramayu oleh pemerintah daerah harus membentuk payung hukum kebijakan yang berbeda dengan kebijakan reguler lainnya. Atmosfer perkotaan pun harus terbangun, seperti penyediaan berbagai fasilitas yang menunjangnya.

3. Oleh karena desain desentralisasi di Indonesia merupakan desain tunggal, yang memberikan perlakuan seragam (simetris) kepada setiap daerah otonom yang ada. Hal ini berarti bahwa pengaturan hubungan pusat-daerah dalam aspek kewenangan, kelambagaan, keuangan, dan pengawasan dibuat sama antara daerah satu dengan daerah lainnya. Padahal setiap daerah memiliki karakteristik yang sangat beragam, termasuk penerapan desain tunggal kebijakan desentralisasi yang tidak sepenuhnya mampu mengatasi berbagai tantangan.

4. Dalam kebijakan desentralisasi ini perlu diarahkan menjadi kajian berupa kebijakan yang dapat mengakomodasikan berbagai perbedaan karakteristik serta kondisi masing-masing daerah. Adapun pemberlakuan (treatment) berbeda ini dikenal dengan sebutan desentralisasi asimetris (asymmetric decentralization). lokal (local responsibility). Ketiga tujuan ini saling berkaitan satu sama lain.

5. Kajian pengembangan desentralisasi asimetris di Indonesia, terutama di Kabupaten Indramayu, yaitu: bagaimana kondisi eksisting penyelenggaraan kebijakan desentralisasi asimetris di kabupaten Indramayu; dan bagaimana model desentralisasi asimetris di Indramayu sebagai kawasan perkotaan yang dapat dijadikan alternatif meminimalisasikan hubungan pusat-daerah, sekaligus dapat mendorong peningakatan daya saing daerah dalam upaya 
percepatan

pencapaian

kesejahteraan masyarakatnya.

\section{Rumusan Masalah}

Berdasarkan pernyataan (problem statment) yang dikemukakan di atas, maka pertanyaan penelitian (research question) yang akan dijadikan dasar penelitian adalah "Bagaimanakah pengembangan model desentralisasi asimetris kawasan perkotaan di Kawasan Kabupaten Indramayu yang mampu mengakomodasi penyelenggaraan pelayanan efektif dan efisien?".

\section{Tujuan Penelitian}

Sesuai dengan masalah penelitian yang dirumuskan di atas, maka yang menjadi tujuan penelitian ini adalah untuk menemukan dan menganalisis faktorfaktor pengembangan model desentralisasi asimetris kawasan perkotaan di Kabupaten Indramayu yang mampu mengakomodaskan penyelenggaran pelayaan efektif dan efisien kepada masyarakat.

\section{Kegunaan Penelitian}

Secara teoretis hasil penelitian ini diharapkan dapat mengembangkan konsep serta merumuskan model efektivitas desentralisasi asimetris kawasan perkotaan dalam meningkatkan pelayanan publik, yang merupakan bagian dari kajian Ilmu Pemerintahan. Dengan demikian hasil penelitian ini bertujuan untuk memberikan kontribusi bagi Ilmu Pemerintahan dengan menemukan konsep baru tentang wilayah dan fungsi pemerintahan dalam tata kawasan perkotaan.

\section{Kegunaan Praktis}

Hasil penelitian ini diharapkan menjadi bahan informasi, pertimbangan dan rekomendasi bagi pemerintah pusat, pemerintah Provinsi Jawa Barat dan pemerintah Kabupaten Indramayu dalam menyusun dan mengimplementasikan kebijakan tentang pengaturan wilayah dan fungsi pemerintahan kawasan perkotaan dalam rangka peningkatan pelayanan kepada masyarakat di masa mendatang.

\section{Kerangka Pemikiran}

Tinjauan atas berbagai konsep di atas membawa peneliti kepada penyusunan suatu kerangka pemikiran yang selanjutnya berfungsi sebagai dasar penggalian data dan analisis temuan. Dari tinjauan atas berbagai konsep di atas, peneliti menyimpulkan bahwa kebutuhan kewenangan khusus wilayah (desa) dapat diperoleh melalui pendekatan dan kriteria penyerahan kewenangan yang berlaku umum bagi desa-desa lain (pertimbangan umum) dan dilengkapi dengan pertimbangan khusus berdasarkan kedudukannya pada kawasan perkotaan khusus.

Dalam pertimbangan umum, sejumlah kerangka pikir berikut menjadi dasar. Pertama, kewenangan khusus bagi desa-desa di kawasan Kabupaten Indramayu menjadi bermakna jika diserahkan dalam kerangka desentralisasi. Artinya, kewenangan khusus tersebut mencakup baik wewenang untuk menetapkan kebijakan maupun wewenang menjalankan kebijakan lewat penyerahan oleh Pemerintah Pusat. Implikasinya, wewenang yang diserahkan menjadi tanggung jawab daerah (desa), termasuk aparat pelaksana dan pembiayaannya. Tentu saja, sebagai prinsip negara kesatuan, dalam urusan khusus Desa tersebut selalu terdapat irisan kewenangan Pemerintah Pusat-setidaknya dalam penetapan kebijakan.

Kedua, penambahan kewenangan secara khusus bagi desa ditentukan pula pendekatan atau cara penyerahan 
kewenangan. Kewenangan khusus tersebut dapat terbentuk jika dilakukan melalui penyerahan dengan pendekatan general-competence atau open-end arrangement. Dengan rumusan lain, penambahan kewenangan secara khusus kepada desa-desa dilakukan melalui penyerahan berdasarkan Sistem Rumah Tangga Daerah Riil yang memang memungkinkan tambahan urusan berdasar pertimbangan faktor-faktor nyata (riil) di wilayah kawasan.

Penelitian masalah kebijakan desentralisasi asimetris di Indonesia saat ini lebih banyak mengangkat kasus otonomi khusus (otsus) seperti di Papua dan Aceh, serta Daerah Istimewa Jogyakarta (DIY) terkait riset-riset advokasi bagi penyusunan RUU penyiapannya. Oleh karena itu, dalam konteks penelitian ini, manfaat edukasi ditujukan untuk memperkaya kebijakan desentralisasi asimetris dengan mengangkat kasus penerapannya di Kabupaten Indramayu, sebagai sumbangan perbaikan kebijakan penataan daerah kawasan Kabupaten Indramayu.

Desentralisasi

(asymmetrical decentralization) merupakan desentralisasi luas mencakup: desentralisasi politik, ekonomi, fiskal, dan administrasi, namun tidak harus seragam untuk semua wilayah negara, mempertimbangkan kekhususan masing-masing daerah. Desentralisasi asimetris adalah pemberlakuan kewenangan khusus pada wilayahwilayah tertentu dalam suatu negara, yang dianggap sebagai alternatif untuk menyelesaikan berbagai permasalahan hubungan antara pemerintah pusat dan daerah. Penerapan kebijakan desentralisasi asimetris atau otonomi asimetris merupakan sebuah manisfestasi dari sebuah pemberlakuan istimewa.
Konsep atau model Desentralisasi Asimetris ini sebenarnya sudah diterapkan pada berbagai daerah di Indonesia, terutama yang berotonomi khusus, seperti: Provinsi Papua, Pemerintahan Aceh, DKI Jakarta, dan Provinsi Daerah Istimewa Jogjakarta. Keempat provinsi tersebut secara legal formal sudah memperoleh pengakuan dari negara, sebagai terbukanya ruang gerak implementasi dan kreativitas provinsi dalam pelaksanaan pemerintahan di luar ketentuan umum dan khusus. Titik berat desentralisasi asimetris terletak pada provinsi, oleh karena level kabupaten atau kota sudah cukup terakomodasikan dalam perundang-undangan pemerintahan daerah selama ini.

Akan tetapi apabila diterapkan pada level kabupaten atau kota, termasuk Kabupaten Indramayu, harus memenuhi kriteria sebagai berikut yaitu adanya faktor-faktor Pengembangan Model Desentralisasi Asimetris (Hutington, 2011) meliputi: (1) adanya rasionalisasi kewenangan, artinya banyak berdiri kokoh kelembagaan pemerintah daerah yang masing-masing memiliki wewenang secara konstitusional atau rule of government; (2) adanya deferensiasi struktur, maksudnya adalah didalam tubuh setiap kewenangan kelembagaan pemerintah daerah terdapat bobot dan ruang lingkup otoritas yang tidak saling sikut, saling klaim, dan saling lempar tanggung jawab. Dalam implementasi penyelenggaraan baik program maupun keputusan politik, untuk kemaslahatan orang banyak, berjalan diatas koridor masing-masing kelembagaan, tanpa adanya tumpang-tindih wewenang serta kepentingan; (3) adanya perluasan peran serta komunikasi politik massa atau rule of law instrument dalam penyelenggaraan kekuasaan pemerintah daerah. Dalam hal ini peran politik 
massa secara aktif dan kritis terhadap landasan filosofis pemerintahan demokratis, yaitu: adanya akuntabilitas, partisipatif, kesepakatan, kesetaraan hak, check and ballance. Apabila diterapkan di Indonesia, keistimewaannya diberikan berdasarkan penghargaan historis dan kultur, misalnya seperti kasus di DIY, tidak adanya kesamaan hak untuk merebut kekuasaan tertinggi di pemerintahan daerah, oleh karena rakyatnya mengakui secara aklamasi bahwa gubernurnya harus dari keturunan raja.

Konsep Model Desentralisasi Asimetris di Kabupaten Indramayu ini sebagai berikut:

Bagan 1:

Model Konsep Pengembangan Model Desentralisasi Asimetri di Kabupaten Indramayu Provinsi Jawa Barat

Rasionalisasi Kewenangan, banyak berdiri kokoh
kelembagaan pemerintah daerah yang masing-masing memiliki
wewenang secara konstitusional
atau rule of government;

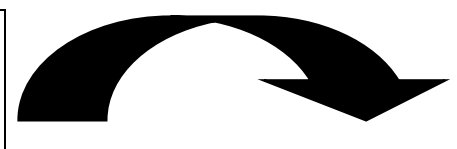

Deferensiasi Struktur, dalam implementasi
penyelenggaraan baik program maupun keputusan politik, untuk
kemaslahatan orang banyak, berjalan diatas koridor masing-masing
kelembagaan, tanpa adanya tumpang-tindih wewenang serta
kepentingan

Perluasan Peran serta Komunikasi Politik Massa atau rule of law instrument dalam penyelenggaraan kekuasaan pemerintah daerah. Dalam hal ini peran politik massa secara aktif dan kritis terhadap landasan filosofis pemerintahan demokratis, yaitu: adanya akuntabilitas, partisipatif, kesepakatan, kesetaraan hak, check and ballance.
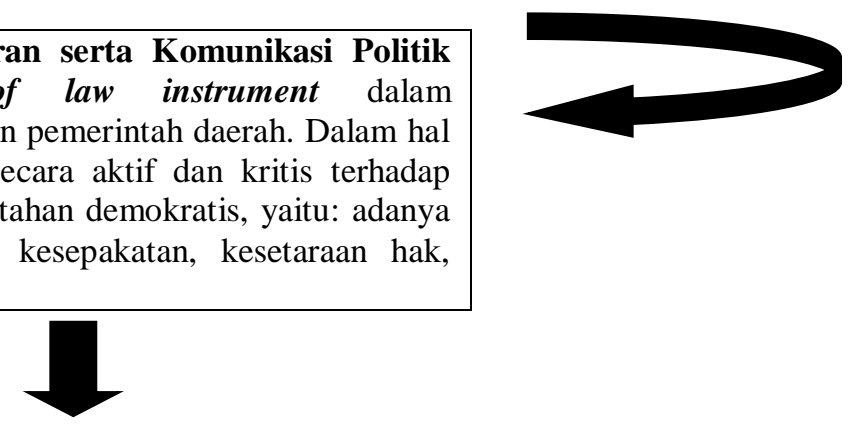

Kabupaten Indramayu harus memiliki keistimewaan yang
diberikan berdasarkan penghargaan historis dan kultur, dan tidak adanya
kesamaan hak untuk merebut kekuasaan tertinggi di pemerintahan daerah,
oleh karena rakyatnya mengakui secara aklamasi bahwa Bupatinya harus dari
keturunan raja atau memiliki hal-hal yang khusus atau bersifat istimewa

\section{METODE PENELITIAN}

\section{Pendekatan dan Metode Penelitian}

Penelitian pengelolaan kawasan perkotaan pada hakikatnya adalah suatu obyek masalah sosial sistemik/kompleks dan menjadi lengkap dengan dikenali melalui kerangka pendekatan verstehen, yang dalam kasus Kawasan Kabupaten Indramayu diperlukan keterlibatan penulis sendiri dalam memahami realitas tersebut dan makna dibaliknya. Atas dasar pertimbangan serta keperluan tersebut, penelitian ini menggunakan metode kualitatif dengan teknik pengumpulan data melalui wawancara mendalam dan didukung dengan kajian kepustakaan.

$$
\text { Dalam metode kualitatif, }
$$
mengikuti pikiran $\mathrm{Creswell}^{4}$, penulis menempatkan status Kawasan

4 John W. Creswell, "Research Design: Qualitative and Quantitative Approaches," California: Sage Publications, Inc., 1994, pp.4-8 
Kabupaten Indramayu sebagai hasil rekonstruksi dinamis individu/institusi yang terlibat dalam pembuatan kebijakan dan penyelenggaraan pemerintahan (ontologis), sementara untuk menangkap cara pandang mereka dan konteks realitas yang ada dilakukan melalui suatu interaksi, sejauh mungkin bisa penulis lakukan secara intensif (epistemologis). Dengan proses demikian, diharapkan secara induktif akan terbentuk interpretasi dan pemahaman makna fungsi serta wilayah perdagangan dan perkotaan di Kabupaten Indramayu dalam kerangka model desentralisasi asimetris. Untuk maksud itu, penelitian ini bertipikal deskriptif ditujukan untuk menggambarkan dan menjelaskan secara analitik mengapa dan bagaimana tipologi (pola-pola) masalah berlangsung. ${ }^{5}$

Dalam rangka pelaksanaan penelitian, rangkaian kerja dimulai dari: (1) studi literatur untuk mengenal (sensitisasi) latar belakang masalah, menelaah landasan konsep/teori dan aspek yuridis Kabupaten Indramayu; (2) sebagai tahapan inti dilakukan penggalian data penelitian induktif lapangan melalui teknik wawancara mendalam kepada Pemerintah Provinsi Jawa Barat, guna memperoleh gambaran tentang kebijakan pemerintah dalam pengaturan, lalu rangkaian wawancara dengan narasumber Pemerintah Kabupaten Indramayu dan pejabat/ institusi terkait dibawahnya serta dengan para pakar dan pihak-pihak lainnya; serta (3) analisis data dan penulisan laporan.

Khusus menyangkut penggalian data (point 2), suatu penelitian kualitatif tentu tidak hanya bersandar pada satu

\footnotetext{
5 Bandingkan dengan Bambang Prasetyo dan Lina Miftahul Janah, "Metode Penelitian Kuantitatif", Jakarta: Rajawali Pers, 2005, hlm.41-43.
}

teknik kerja, tetapi gabungan dua/lebih sumber data sesuai dengan keperluan fokus dan tujuan penelitian. Dalam penelitian ini dipakai satu teknik utama: wawancara mendalam (in depth interview) kepada sejumlah narasumber, baik secara individual maupun kolektif kepada lebih dari satu narasumber pada satu kesempatan yang sama, dipandu dengan instrumen panduan wawancara yang disusun secara umum. Namun, guna memperkaya analisis, penelitian ini dibantu dengan teknik pendukung berupa kajian pustaka, terutama yang berisi data kualitatif (regulasi, tulisan pakar dan lain-lain) yang dinilai penting dan relevan dengan isi bahasan.

\section{Teknik Penentuan Narasumber}

Sesuai dengan prinsip pendekatan kualitatif, pilihan narasumber penelitian ini tidak ditarik dari populasi melainkan secara purposif, dan membuka kemungkinan melakukan penelusuran narasumber secara snowbolling. Para narasumber yang diwawancari adalah kalangan akademisi/pakar bidang pemerintahan lainnya, tokoh masyarakat/ LSM yang bergerak dalam masalah di Kabupaten Indramayu, Pemda Provinsi Jawa Barat, Pemda Kabupaten Indramayu maupun jajaran pejabat terkait, unsur DPRD Provinsi Jawa Barat dan Kabupaten Indramayu, dan lain-lain yang terkait dengan masalah yang diteliti.

Meski dipilih berdasarkan unsur kelembagaan, satuan yang menjadi sumber data adalah individu/pribadi yang memimpin suatu institusi terkait atau memiliki kompetensi akademik/profesional. Afiliasi kelembagaan dalam organisasi tertentu tidak dilihat dalam kerangka sebagai perwakilan institusi tersebut karena satuan data tetap sepenuhnya adalah pada individu sebagai sumber informasi. Penyebutan jabatan atau asal 
institusi dalam penulisan laporan lebih ditempatkan sebagai atribut individu yang bersangkutan. Dalam situasi saat variasi pendapat narasumber tidak berpola atau kontradiktif secara ekstrim serta dilakukan konfirmasi kepada narasumber (kunci) guna memperoleh kejelasan lebih lanjut ${ }^{6}$.

\section{Tahapan Analisis Data}

Dalam suatu pendekatan kualitatif, analisis data bersifat induktif (grounded $)^{7}$. Analisis dan kesimpulan dilakukan dengan "mengabstraksikan" informasi/data yang dikumpulkan, dan mencari suatu tipologi atau pola-pola khas yang dapat dibangun dari informasi/data tersebut. Proses analisis telah dilakukan bersamaan dan sepanjang penelitian dilakukan, sementara proses pengumpulan informasi/data berhenti (selesai) pada titik jenuh profil data yang menggambarkan ketercukupan kebutuhan data dalam penilaian peneliti.

Dengan data/informasi utama yang berasal dari hasil wawancara mendalam dan didukung sumber dokumentasi terkait, proses analisis telah dilakukan melalui rangkaian langkah berikut: transkrip isi rekaman berdasar kronologis wawancara dan pengelompokan data (coding) yang berisi ragam pendapat berdasarkan kategorisasi tertentu, dan selanjutnya dalam tahap analisis dilakukan

\footnotetext{
6 Namun demikian, konfirmasi ini tidak bisa digolongkan sebagai teknik triangulasi karena upaya tersebut hanya dilakukan dalam teknik yang sama (wawancara mendalam), bukan melalui teknik lain (seperti Focused Group Discussion/FGD) yang memang ditujukan untuk keperluan uji silang data dan mencari makna intersubyektif sebagai data kelompok agar hasil analisis semakin akurat

7 Dr. Prasetya Irawan, M.Sc, "Penelitian Kualitatif dan Kuantitatif untuk Ilmu-ilmu Sosial", Jakarta: Departemen Ilmu Administrasi FISIP UI, 2006, hlm.53
}

penguraian berdasar hasil wawancara dan data-data lainnya guna memperoleh makna/pemahaman dibaliknya, lalu memberikan tafsiran (interpretasi) dalam rangka mengembangkan analisis untuk menjawab tujuan penelitian, serta akhirnya menarik kesimpulan dan rekomendasi.

Penelitian kebijakan dalam pembahasan ini yaitu suatu ketetapan yang memuat prinsip-prinsip untuk mengarahkan cara-cara bertindak yang dibuat secara terencana dan konsisten dalam mencapai tujuan tertentu.

James H.Mc Millan dan Sally Schumacher (2015) dalam "Research in Education" menyatakan Policy analysis evaluates government policies to provide policymakers with pragmatic action-oriented recommendations. Policy is both what is intended to be accomplished by government action and the cumulative effort of actions, assumptions, and decisions of people who implement public policy.

Akan tetapi jika kita menyinggung kata penelitian, maka hal ini akan bersentuhan dengan sesuatu yang bernuansa ilmiah. Jadi, dapat dinyatakan bahwa penelitian kebijakan hadir untuk mengilmiahkan kebijakan atau menghasilkan kebijakan yang dapat dipertanggungjawabkan secara ilmiah, dalam batas-batas yang tidak berbenturan keras dengan political will atau lingkungan sosial politik di suatu negara.

\section{Informan}

Informan dalam penelitian ini dipilih secara purposive yaitu:

1. Pejabat Pemerintah Kabupaten Indramayu yang terdiri dari: Bupati, Sekretaris Daerah, dan pejabat lain Kepala Bagian Keuangan, Kepala Dinas Data dan Pelaporan, Kepala Dinas Pendidikan Kabupaten 
Indramayu, yang membidangi serta berhubungan langsung dengan kerangka kebijakan di Pemerintah Daerah Kabupaten Indramayu serta fungi-fungi kewenangan dan desentralisasi, dipilih Camat Jatibarang dan Camat Haurgeulis.

2. Anggota DPRD Provinsi Jawa Barat dan anggota DPRD Kabupaten Indramayu yang menguasai permasalahan perkembangan kebijakan di Kabupaten Indramayu, dari historis dan kondisi kekinian, substansi muatan dalam kebijakan yang digulirkan, serta kondisi desentralisasi di Kabuparen Indramayu dengan konstruksi kewenangan dan fungsifungsinya.

3. Unsur Masyarakat (perwakilan dari Perguruan Tinggi dan Lembaga Swadaya Masyarakat), yang merasakan manfaat sesungguhnya kebijakan strategis Pemerintah Daerah Kabupaten Indramayu, tantangan yang dihadapi, serta keterlibatan partisipasi dan kontrol masyarakat sebagai basis demokrasi lokal serta kebermanfaatan pelayanan publik dari Pemerintah Daerah Kabupaten Indramayu.

\section{Teknik Pengumpulan Data}

Pengumpulan data dan informasi yang dibutuhkan dalam penelitian ini menggunakan teknik: wawancara dan observasi langsung. Melalui cara tersebut dapat ditarik data, baik yang bersifat primer maupun sekunder.

\section{Wawancara}

Untuk melengkapi data yang diperoleh melalui wawancara terhadap informan, yaitu: Pejabat Pemerintah Kabupaten Indramayu yang terdiri dari: Bupati,
Sekretaris Daerah, dan pejabat lain Kepala Bagian Keuangan, Kepala Dinas Data dan Pelaporan, Kepala Dinas Pendidikan Kabupaten Indramayu, yang membidangi serta berhubungan langsung dengan kerangka kebijakan di Pemerintah Daerah Kabupaten Indramayu serta fungi-fungi kewenangan dan desentralisasi, dipilih Camat Jatibarang dan Camat Haurgeulis, dan anggota DPRD Kabupaten Indramayu, perwakilan dari Perguruan Tinggi di Kabupaten Indramayu, serta perwakilan dari Lembaga Swadaya Masyarakat (LSM) di Kabupaten Indramayu Provinsi Jawa Barat.

\section{Observasi}

Observasi merupakan upaya pengamatan langsung dari peneliti, yang menggunakan seluruh kemampuan panca-indera, guna melihat, mengamati, menilai serta menyimpulkan kondisi empirik, berdasarkan fakta yang terdapat di tempat penelitian. Hasil dari observasi langsung ini bisa dijadikan bahan pendukung dan bahan komparasi (cross check) dari fakta yang diperoleh melalui wawancara.

\section{PEMBAHASAN}

\section{Pengembangan Inovasi dan Teknologi Informasi Dalam Pelayanaan Pemda Kabupaten Indramayu yang Efektif dan Efisien}

Pemerintah Pusat dan Pemerintah Provinsi Jawa Barat mulai melirik Kabupaten Indramayu, dalam pengembangan inovasi, ilmu pengetahuan dan teknologi (Iptek), seperti keberadaan Rumah Ilmu Pengetahuan dan Teknologi Mutiara Bangsa, Indramayu yang terletak di sekitar Waduk Bojongsari, Sindang. Kementerian Riset dan Teknologi Republik Indonesia mendukung sepenuhnya keberadaan rumah Iptek 
tersebut, agar bisa berkembang dan melahirkan para ilmuwan muda dari Kabupaten Indramayu.

Seperti yang terungkap dalam hasil wawancara dengan Bupati Indramayu $\mathrm{Hj}$. Anna Sophanah Irianto (Bupati terpilih dilantik Februari, 2016) melalui Sekretaris Daerahnya, Ahmad Bahtiar, S.H. menjelaskan bahwa kunjungan tim dari Kementrian Riset dan Teknologi, telah dilakukan pada tahun 2015 di Indramayu. Selanjutnya, Bahtiar menambahkan bahwa rumah Iptek Mutiara Bangsa tersebut dibangun selama 7 tahun. Pada bulan Mei tahun 2016 mendatang, proses pembangunan gedung akan selesai, dan bisa langsung diisi dengan berbagai alat peraga Iptek, yang telah disediakan oleh Pemkab Indramayu dan juga Kementerian Riset dan Teknolgi RI.

Menurut Bupati Indramayu, dalam arsip pidatonya, bahwa mimpi untuk mewujudkan rumah Iptek Mutiara Bangsa itu berawal ketika Indramayu dipimpin oleh DR. Irianto MS. Syafiuddin (Yance, mantan Bupati Indramayu sebelumnya). Rumah Iptek yang berdiri di Indramayu ini, diharapkan bisa menyamai rumah Iptek yang ada di Singapura. "Keinginan itu muncul sampai dengan saat ini. Rumah Iptek ini diharapkan bisa mencerdasakan generasi muda dari Indramayu, dan melahirkan para ilmuwan muda yang dapat mengetahui ilmu dan pengetahuan dari rumah Iptek ini. Bulan Mei mendatang bangunan ini selesai, dan nanti akan diresmikan oleh Menristek pada hari jadi Indramayu bulan Oktober 2016 mendatang".

Sementara itu, informan dari tokoh masyarakat di Kabupaten Indramayu, menyatakan bahwa apa yang dilakukan oleh Kabupaten Indramayu sangat luar biasa. Oleh karena, selama 7 tahun ini, Indramayu telah menyiapkan sarana dan prasarana untuk mencetak generasi muda manjadi seorang ilmuwan. "Untuk dapat menghidupkan rumah Iptek Mutiara Bangsa ini, bisa beroperasi dengan sehat sesuai dengan manajemen modern. Maka harus diciptakan suatu sistem yang kuat dan professional, serta dipegang oleh orang yang memiliki visi kedepan untuk kemajuan ilmu dan pengetahuan. Adapun untuk mendukung rumah Iptek Mutiara Bangsa di Indramayu ini, dari Kemenristek telah memberikan bantuan alat peraga dan kerjasama dengan Pemkab Indramayu," ungkapnya.

Selanjutnya, Kepala Dinas Pendidikan Kabupaten Indramayu, Odang Kusmayadi selaku informan menambahkan bahwa sebanyak 66 alat peraga saat ini tengah diajukan lagi ke Kemenristek RI, untuk ditindaklanjuti dan tengah dilakukan perjanjian kerjasama. Bahkan rumah Iptek Mutiara Bangsa ini, jika dimungkinkan akan dibuatkan pula teropong angkasa, untuk mempelajari astronomi bagi para pelajar dan masyarakat.

Selain itu, kebijakan lain yang telah dilakukan Pemda Kabupaten Indramayu adalah keberadaan pesisir dan pulau di wilayah Kabupaten Indramayu. Hal ini yang dilakukannya terhadap keberadaan Pulau Biawak, pulau yang terletak sekitar $40 \mathrm{~km}$ utara Indramayu ini sedang berbenah diri sebagai tempat tujuan wisata di Jawa Barat. Secara administrasi wilayah pulau biawak masih masuk Kabupaten Indramayu, pulau yang belum banyak tersentuh manusia ini menawarka pesona keberadaan biawal liar dan pemandangan alam yang begitu indah disapanjang pesisir pulau. Inilah potensi yang perlu segera mendapat tanggapan dan perhatian khusus hingga kelak Pulau Biawak disamping sebagai tempat konservasi juga dapat sebagai tempat tujuan wisata. Sekalipun pemerintah 
daerah dan pemerintah pusat telah berusaha sekuat tenaga untuk mengembangkan Pulau Biawak sebagai kawasan konservasi, kini memang membutuhkan peran serta dari dunia usaha untuk ikut mengembangkan kawasan ini agar bisa menjadi unggulan wisata bagi Kabupaten Indramayu. Informan dari anggota DPRD Kabupaten Indramayu menjelaskan bahwa peran swasta diperlukan untuk mempercepat akselerasi pengembangan Pulau Biawak agar terjaga keasriannya di satu sisi, tetapi pada sisi lain, juga bisa memicu pertumbuhan perekonomian daerah. Kedepannya diharapkan keberadaan Pulau Biawak bisa sejajar dengan tempat wisata di Jawa Barat seperti; Tangkuban Perahu, Pantai Pangandaran, Pelabuhan Ratu, Puncak Pass serta obyek wisata lain di Jawa Barat.

Hasil wawancara dengan informan dari akademisi (perwakilan PT) dinilai bahwa saat ini Kabupaten Indramayu memerlukan sosok pemimpin yang sesuai harapan dan keinginan rakyat, untuk lima tahun mendatang 2015-2020. Kemudian tokoh masyarakat lain, Juju Juhaeriyah, menyatakan bahwa pemimpin untuk Kabupaten Indramayu mendatang, gampang-gampang susah. Oleh karena perlu adanya pemimpin yang berkualitas dalam memajukan Kabupaten Indramayu, termasuk melahirkan kebijakan-kebijakan yang pro rakyat. "Orang yang memiliki kriteria sebagai pemimpin, cukup banyak. Tapi memang ada kelebihan dan kekurangan-nya sih. Namun, saya suka untuk pemimpin Indramayu kedepan, berasal dari kalangan pendidikan atau akademisi. Oleh karena saat ini, Indramayu butuh perubahan untuk kemajuan dan kecerdasan masyarakatnya". Menurut Juju
Juhaeriyah, yang juga berasal dari wilayah Kecamatan Sukraini.

\section{Pengembangan Desentralisasi Asimetris di Kabupaten Indramayu}

Desentralisasi asimetris (asymmetrical decentralization) merupakan desentralisasi luas mencakup desentralisasi politik, ekonomi, fiskal, dan administrasi, namun tidak harus seragam untuk semua wilayah negara, mempertimbangkan kekhususan masing-masing daerah. Inti desentralisasi asimetris adalah terbukanya ruang gerak implementasi dan kreativitas provinsi dalam pelaksanaan pemerintahan di luar ketentuan umum. Jika dilihat dari ketiga (3) Undang-Undang kehususan dan keistimewaan dalam Provinsi DIY, Aceh dan Papua telah menggambarkan penerapan desentralisasi asimetris. DIY memiliki pengaturan yang khas pada tata cara pengisian jabatan, kedudukan, tugas, dan wewenang Gubernur dan Wakil Gubernur, kelembagaan Pemerintah Daerah DIY, kebudayaan, pertanahan, dan tata ruang. Aceh memiliki pengaturan yang khusus mengenai penyelenggaran kehidupan beragama, kehidupan adat, penyelenggaraan pendidikan dan peran ulama dalam penetapan kebijakan Daerah serta pemberdayaan perekonomian Aceh. Papua memiliki pengaturan yang khusus mengenai bidang pemerintahan, perekonomian dan hak masyarakat dan hak asasi manusia.

Hasil wawancara dengan anggota DPRD Provinsi Jawa Barat, Bambang Haryono, bahwa Gubernur DIY, Sri Sultan Hamengkubuwono $X$ telah membawa desentralisasi di DIY dengan mengakomodasi perbedaan perlakuan tiap-tiap daerah. Oleh karena, dalam UUD 1945 telah menjamin kebhinekaan Indonesia, tetapi dalam 
pelaksanaan bernegara, tata kelola dan manajemen yang dijalankan lebih berfokus kepada ke-ika-an (simetrisme) Indonesia. "Buktinya, model desentralisasi belum mengadopsi prinsip desentralisasi asimetris yang mengakui keberagaman kondisi daerah yang tercermin dan diakui dalam unitunit pemerintah daerah dengan tingkatan otonomi dan tanggung jawab yang berbeda," (sumber lain, Tribunnews.com, 2015). Lebih lanjut menurut Haryono (wawancara, 2016) bahwa "Seyogyanya, ada perbedaan perlakuan (treatment) antara satu daerah dan daerah yang lain dengan mempertimbangkan keragaman potensi daerah. Hal ini akan membantu proses mobilisasi sumber daya daerah dan sumber daya pemerintah yang lebih efisien untuk meningkatkan masyarakat di daerah. Inilah esensi desentralisasi dan otonomi daerah yang dibangun di Indonesia pasca reformasi," jelasnya. Penulis dengan sumber lain (Tribun.com, 2015) bahwa untuk mencapai tujuan ini, di DIY diterapkan jenis-jenis otonomi yang ada di Indonesia (otonomi reguler dan otonomi khusus) yang menjadi bukti empiris yang bisa dijadikan dasar untuk pengadopsian konsep desentralisasi asimetris. Selain itu, secara teoritis, ada 4 alasan pendukung yakni historis konstitusi, politis, sosial budaya dan ekonomi.

"Sejarah bergabungnya Yogyakarta dengan NKRI adalah rujukan kuat bagi proses pengadopsian model desentralisasi asimetris," (Sultan, Tribun.com, 2015) Kebijakan desentralisasi asimetris sangat patut dipertimbangkan untuk mengurangi kecenderungan pemekaran daerah yang dianggap sebagai solusi untuk merespon kebutuhan aktualisasi kekhasan kultural, sosial dan ekonomi. Tidak hanya itu, hal tersebut juga mampu mendorong percepatan kesejahteraan rakyat sesuai dengan kondisi kekhasan di daerah. "Juga bisa mendorong percepatan daya saing daerah berbasis pada potensi lokal, mendukung daya saing dan kesetaraan antar daerah dan memperkuat otonomi substantif sebagai pilar sistem demokrasi NKRI." Oleh karena itu, apabila desentralisasi asimetris ini bisa diadopsi sebagai alternatif solusi penyempurnaan sistem desentralisasi di Indonesia yang mampu menciptakan pemerintah daerah yang stabil, kondusif dan demokratis, maka impian para pendiri bangsa untuk mewujudkan kesejahteraan rakyat Indonesia sesuai amanat UUD 1945 bisa dicapai.

Lebih lanjut, hasil wawancara dengan informan dari anggota DPRD Kabupaten Indramayu dan tokoh dari Perguruan Tinggi menjelaskan bahwa formasi utama desentralisasi asimetris adalah demokrasi sekaligus memperkuat NKRI. Inti desentralisasi asimetris ini adalah terbukanya ruang gerak implementasi dan kreativitas provinsi dalam pelaksanaan pemerintahan diluar ketentuan umum dan khusus. Akan tetapi, walaupun sebagai terobosan baru, dalam mekanismenya di kabupaten atau kota dapat menimbulkan kebuntuan formal. Misalnya, lanjut informan, dalam rangka pengakuan dan pengembangan hak-hak adat, kekayaan intelektual masyarakat, serta keadilan dalam perspektif hubungan pusat-daerah, yang diperlukan solusi interpretatif cerdas tanpa mengurangi kehati-hatian dalam memberikan kewenangan lebih besar kepada provinsi.

Hal ini sebagaimana dikemukakan Hutington (2011), bahwa untuk implementasi desentralisasi asimetri harus memenuhi kriteria sebagai berikut: (1) adanya rasionalisasi kewenangan; (2) adanya deferensiasi 
struktur; (3) adanya perluasan peran serta komunikasi politik massa atau rule of law instrument penyelenggaraan kekuasaan pemerintah daerah. Artinya, pertama, banyak berdiri kokoh kelembagaan pemerintah daerah yang masing-masing memiliki wewenang secara konstitusional atau rule of government; kedua, deferensial struktur maksudnya adalah didalam tubuh setiap kewenangan kelembagaan pemerintah daerah, terdapat bobot dan ruang lingkup otoritas yang tidak saling sikut, saling klaim, dan saling lempar tanggung jawab. Artinya implementasi penyelenggaraan baik program maupun keputusan politik, untuk kemaslahatan orang banyak, berjalan diatas koridor masing-masing kelembagaan, tanpa adanya tumpang-tindih; ketiga, peran politik massa secara aktif dan kritis terhadap landasan filosofis pemerintahan demokratis, yaitu: adanya akuntabilitas, partisipatif, kesepakatan, kesetaraan hak, check and ballance. Apabila diterapkan di Indinesia, keistimewaannya diberikan berdasarkan penghargaan historis dan kultur, misalnya seperti kasus di DIY, tidak adanya kesamaan hak untuk merebut kekuasaan tertinggi di pemerintahan daerah, oleh karena rakyatnya mengakui secara aklamasi bahwa gubernurnya harus dari keturunan raja.

Menurut Ryaas Rasyid (2011) bahwa sebagai tokoh pemrakarsa otonomi daerah sekaligus mantan Menteri Otonomi Daerah, daerah harus mampu mengoptimalkan sumber daya yang dimiliki dengan kemampuan sendiri dan menanganinya sekreatif mungkin. Hal itu diwujudkan dengan pergantian kebijakan dari UndangUndang Nomor 5 Tahun 1974 yang menghasilkan mekanisme pemerintahan yang sentralistik, menjadi UndangUndang Nomor 22 Tahun 1999 tentang Pemerintahan Daerah dan Undang-
Undang Nomor 25 Tahun 1999 tentang Perimbangan Keuangan antara Pemerintah Pusat dan Daerah yang kemudian direvisi menjadi UndangUndang Nomor 32 Tahun 2004 dan Undang-undang Nomor 23 Tahun 2014. Dengan adanya kebijakan tersebut, diharapkan mampu meningkatkan pertumbuhan daerah dengan pembangunan yang fokus dan terarah. Namun pada kenyataannya, sejak diterapkan pada 1 Januari 2001, praktek desentralisasi tidak berjalan sesuai harapan. Permasalahan baru bermunculan, sementara tujuan mulia desentralisasi seolah sulit diwujudkan. Permasalahan-permasalahan tersebut antara lain: timbulnya korupsi di kalangan pejabat pemerintah, timbulnya pemekaran wilayah dan ketimpangan antar wilayah sampai pada sengketa yang terjadi akibat dari pemekaran wilayah.

Sebagaimana bergulirnya suatu kebijakan pada umumnya, lanjut Rasyid (2011), bahwa praktek desentralisasi ini memiliki sisi positif dan sisi negatif. Hal baik yang dapat diambil dari keberadaan desentralisasi ini adalah semakin meningkatnya kemampuan pemerintah daerah dalam mengatur wilayahnya sendiri tanpa harus didikte oleh pusat. Kemungkinan kesalahan perencanaan pembangunan dapat dikurangi karena pemerintah daerah lebih mengetahui dan memahami karakter wilayahnya sendiri sehingga pembangunan dapat terlaksana sesuai dengan potensi yang ada dengan mengarah kepada tujuan. Pejabat pemerintahan di daerah juga lebih dapat bertanggung jawab karena melakukannya secara mandiri atas apa yang dilakukan pada wilayahnya sendiri. Dengan keleluasaan tersebut, diharapkan kreativitas daerah dalam mengatasi berbagai permasalahan domestik akan terpacu dan mampu 
meningkatkan kapabilitasnya sebagai wilayah yang tidak hanya memiliki kekayaan sumber daya alam saja, namun juga sumber daya manusianya. Dengan demikian, kesejahteraan masyarakat di daerah dapat tercapai dan kesenjangan sosial atas tidak meratanya pembangunan dengan wilayah pusat dapat dikurangi. Sementara itu, tugas pemerintah pusat lebih dapat terorganisir dengan berkurangnya wewenang atas pembangunan di daerah. Pemerintah pusat dapat lebih berkonsentrasi terhadap permasalahan makro yang harus dihadapi negara. Pemerintah juga dapat mengatur pembangunan secara nasional dan mengawasi jalannya pembangunan agar pemerataan daerah dapat tercapai. Selain itu, pemerintah pusat juga dapat lebih fokus memajukan dan melindungi negara dari ancaman baik dari dalam maupun dari luar negeri. Namun tujuan perubahan sistem dari sentralistik topdown menjadi desentralistik bottom-up tidak selamanya berdampak baik. Bahkan banyak permasalahan baru yang timbul, seperti: banyaknya korupsi, kolusi, dan nepotisme di daerah-daerah.

\section{Pengembangan Model Asimetris Mengakomodasi Penyelenggaraan Pelayanan Efektif dan Efisien}

Otonomi Daerah menjadi gagasan baik setelah pemerintahan Orde baru, yang diyakini sebagai formula yang ampuh dalam mengakhiri permasalahan dan ketidakharmonisan hubungan antara pemerintah pusat dan daerah. Otonomi dalam maksa sempit yang diartikan sebagai "mandiri" atau dalam arti luas 'berdaya". Arti penting otdadesentralisasi adalah:
1. Untuk terciptanya efesiensi- efektivitas penyelenggaraan pemerintahan.

2. Sebagai sarana pendidikan politik.
3. Pemerintah daerah senagai persiapan untuk karier politik lanjutan.

4. Stabilitas politik.

5. Kesetaraan politik.

6. Akuntabilitas publik.

Visi otda merupakan simbol adanya kepercayaan dari pemerintah pusat ke daerah. Visi merupakan gambaran umum cita-cita yang akan dicapai, visi otda adalah:

1. Politik, harus dipahami sebagai sebuah proses untuk membuka ruang bagi lahirnya kepala pemerintah daerah yang dipilih secara demokraris, memumgkinkan berlangsungnya pemerintahan yang reprosensif.

2. Ekonomi, terbukanya peluang bagi pemerintah daerah dalam mengembangkan kebijakan regional dan lokal untuk mengoptimalkan pendayagunaan potensi ekonomi di derahnya.

3. Sosial, menciptakan kemampuan masyarakat untuk merespon dinamika kehidupan di sekitarnya.

Rondinelli (1983) menjelaskan modelmodel otonomi daerah dalam empat bentuk desentralisasi sebagai berikut:

1. Dekonsentrasi, merupakan pembagian kewenangan dan tanggung jawab administratif antara pemerintah pusat dengan pejabat pusat di lapangan tanpa adanya penyerahan kewenangan untuk mengambil keputusan.

2. Delegasi, merupakan pelimpahan pengambilan keputusan dan kewenangan manajerial untuk melakukan tugas khusus kepada suatu organisasi yang tidak secara langsung berada di bawah pengawasan pemerintah pusat.

3. Devolusi, merupakan transfer kewenangan untuk pengambilan 
keputusan, keuangan dan manajemen kepada unit pemerintahan daerah. Bentuk ini memiliki lima karakteristik. Pertama, unit pemerintahan lokal bersifat otonom, mandiri, dan secara tegas terpisah dari tingkat pemerintahan. Kedua, unit pemerintahan lokal diakui mempunyai batas yang legal, yang mempunyai kewenangan untuk melakukan tugas umum pemerintahan. Ketiga, unit pemerintahan daerah berstatus sebagai badan hukum yang berwenang dan memanfaatkan sumberdaya untuk mendukung pelaksanaan tugasnya. Keempat, unit pemerintahan lokal diakui oleh warganya sebagai suatu lembaga yang akan memberikan wewenang kepada masyarakat dan memenuhi kebutuhan mereka. Kelima, terdapat hubungan yang saling menguntungkan melalui koordinasi antara pemerintah pusat dan derah serta unit organisasi lain dalam suatu sistem pemerintahan.

4. Privatisasi, merupakan tindakan pemberian kewenangan dari pemerintah kepada badan-badan sukarela, swasta, dan swadaya masyarakat.

Dalam hal pengaturan kewenangan di Kabupaten Indramayu, dari analisis peraturan dan legalitas kewenangan dan keterangan para nara sumber bahwa efisiensi dan efektivitas untuk mengatur dan/atau mengurus urusan-urusan di kabupaten/kota, penunjukkan Kabupaten Indramayu sebagai "satu dalam arah perencanaan, pelaksanaan, dan pengendalian pembangunan" dalam tataran rasionalitas kebijakan sulit dinalarkan bagaimana mengaitkan bagaimana kebutuhan kewenangan sebagai suatu daerah khusus dalam desentralisasi asimetris, dengan bentuk otonomi tunggal. Sementara pada tataran implementasinya perlu dilakukan otonomi tunggal di Kabupaten Indramayu, dengan menciptakan fenomena mikrosentralisasi-kewenangan, yang menjadikan Kabupeten Indramayu mempunyai kewenangan administratif Provinsi Jawa Barat sebagai bawahannya, bukan lagi kewenangan pusat dan daerah, hal ini menjadikan Kabupaten Indramayu menjaga jarak denga masyarakatnya sebagai pusatlayanannya, serta menjadikan demokrasi tidak berhenti di level provinsi tapi pada level kabupaten atau kota.

\section{Konsep Kewenangan Pemerintah Daerah Kabupaten Indramayu}

Penyelenggaraan pemerintahan di suatu negara dilakukan pertama-tama menurut azas sentralisasi saat semua pembuatan dan pelaksanaan kebijakan berlangsung sepenuhnya pada tataran nasional, baik secara terpusat maupun melalui instansi (field administration, local state government) di daerah yang memperoleh pelimpahan wewenang dan membentuk relasi kewenangan intraorganisasi dalam rangka asas dekonsentrasi. Akan tetapi, dalam perkembangannya saat ini pengelolaan organisasi negara (terutama yang berukuran besar, memiliki masalah yang kompleks), yaitu melibatkan pemerintah lokal, dan pemerintah pusat hanya menetapkan pokok kebijakan (makro), sementara jabaran (kebijakan mikro) dan implementasinya diserahkan kepada pemerintah lokal sebagai institusi Daerah Otonom. Pelibatan pemerintah derah dan penyerahan kewenangannya merupakan inti Desentralisasi. 
Dengan penerapan desentralisasi kewenangan ini, keberagaman lokal (daerah/masyarakat) yang terlibat pada aspirasi politik, struktur sosial dan potensi ekonomi diperhatikan dalam pengelolaan negara melalui pelimpahan kewenangan pembuatan kebijakan (mengatur) dan penerapannya (mengurus) ke unit-unit pemerintahan lokal yang lebih mengenal kondisi daerah/masyarakatnya (dengan dasar pikir demikian, Prof.Bhenyamin Hoessein menekankan makna desentralisasi sebagai pengotonomian atau otonomisasi, yaitu proses memberikan otonomi kepada masyarakat dalam wilayah (teritori) tertentu. Subyek otonomi adalah masyarakat yang mendiami teritori tersebut.

Dalam hal kewenangan, terjemahan prinsip desentralisasi pada negara unitaris ini dijabarkan bahwa: (1) selalu ada unsur yang sepenuhnya diselenggarakan pusat (urusan eksklusif); (2) terdapat sejumlah urusan atau bagian urusan atau kegiatan dalam suatu urusan yang dapat didesentralisasi, tetapi sifatnya tidaklah mutlak atau eksklusif.

Hasil wawancara dengan informan anggota DPRD Provinsi Jawa Barat, Bambang Haryono, bahwa sejak pelaksanaan otonomi daerah, ketergantungan pemerintah Provinsi Jawa Barat terhadap pusat justru semakin tinggi. Hal ini terlihat dari tingginya dana transfer dari pemerintah pusat dari $58,17 \%$ menjadi $67,61 \%$. Dana tersebut digunakan untuk membiayai pembelajaan pemerintah daerah. Hal ini berbanding lurus dengan semakin meningkatnya pengeluaran daerah dari Rp. 647,46 milyar menjadi Rp. 3.474,8 milyar dengan pengeluaran tertinggi adalah pengeluaran rutin daerah yang digunakan untuk belanja pegawai yang jumlahnya juga meningkat (data DPRD Provinsi Jawa Barat 2013). Adapun apabila dilihat dari proporsi PAD terhadap APBD, pada tahun 2000 meningkat dari $31 \%$ menjadi $48,1 \%$. Namun PAD terbesar berasal dari pajak daerah dengan kontribusi 94\%. (http://smeru.or.id diakses 15 April 2013).

Setahun setelah penerapan desentralisasi, Jawa Barat mengalami penambahan kota dan kabupaten, bahkan pembentukan provinsi baru, yaitu Provinsi Banten yang didasari oleh Undang-undang Nomor 23 tahun 2000 dengan wilayah cakupan 4 kabupaten (Tangerang, Serang, Pandeglang dan Lebak) serta 2 kota (Tangerang dan Cilegon) (http://smeru.or.id diakses 15 April 2013). Bahkan sekarang ini ada wacana untuk membentuk provinsi baru, yaitu Provinsi Cirebon yang terdiri dari kecamatan-kecamatan yang berada di wilayah pantai utara, antara lain Subang, Indramayu, Majalengka, Cirebon, dan Kuningan (http://antarajawabarat.com diakses 15 April 2011). Apabila dibandingkan uraian sebelumnya mengenai anggaran dana, kebijakan, dan dikotomi kekuasaan, maka pemekaran di wilayah Jawa Barat seharusnya dikaji ulang karena semua dapat berakibat pada menurunnya kesejahteraan masyarakat Jawa Barat itu sendiri, lanjut Bambang Haryono (hasil wawancara).

Pengelolaan daerah secara mandiri memang tidak mudah. Sikap profesionalitas merupakan kunci utama dalam menyukseskan otonomi daerah. Pejabat daerah seharusnya bersih dari permasalahan korupsi, mampu berpikir kreatif dalam mengelola kekayaannya dan bukan hanya terpaku pada pajak serta retribusi daerah sebagai upaya peningkatan $\mathrm{PAD}$. Pembagian tugas pemerintah baik pusat maupun daerah juga harus jelas. Komunikasi yang baik 
antara pejabat pemerintahan dapat meminimalisir perbedaan tingkat kepentingan. Kerjasama antar daerah juga dapat menjadi suatu solusi permasalahan otonomi. Perasaan saling melengkapi dan membutuhkan serta merasa saling memiliki sebagai penduduk NKRI dapat dijadikan pondasi untuk membangun kerjasama tersebut. Dengan demikian, pemerataan pembangunan dapat tercapai sehingga kesejahteraan masyarakat mampu terwujud, ujar Bambang Haryono.

\section{Adapun faktor-faktor}

Pengembangan Model Desentralisasi Asimetris Kawasan Indramayu, menurut Agung (informan dari PT di Kabupaten Indramayu) bahwa: ada beberapa skema model desentralisasi asimetris yang dapat diterapkan untuk pengelolaan batas wilayah negara dan kawasan perbatasan ke depan. Pertama, menyerahkan sepenuhnya urusan pengelolaan kawasan perbatasan negara kepada daerah. Skema kedua, membentuk badan-badan otonom di daerah di bawah koordinasi BNPP. Skema kedua ini belajar dari pengalaman pengelolaan Badan Otorita Batam. Lanjut Aung, bahwa sesuai dengan prioritas Presiden Joko Widodo "Kami akan membangun Indonesia dari pinggiran dengan memperkuat daerahdaerah dan desa dalam kerangka Negara Kesatuan. Kami akan meletakkan dasardasar bagi dimulainya desentralisasi asimetris. Kebijakan desentralisasi asimetris ini dimaksudkan untuk melindungi kepentingan nasional Indonesia di kawasan-kawasan perbatasan, memperkuat daya saing ekonomi Indonesia secara global, dan untuk membantu daerah-daerah yang kapasitas berpemerintahan belum cukup memadai dalam memberikan pelayanan publik...". Oleh karena Negara Kesatuan Republik Indonesia (NKRI) merupakan negara kepulauan yang bercirikan nusantara (nusa dan antara), yaitu menggambarkan wilayah kepulauan yang membentang dari Sabang sampai Merauke, dari Pulau Miangas sampai Pulau Rote, terdiri dari 17.667 pulau dengan penduduk 257 juta jiwa yang tersebar di 34 provinsi, 512 kabupaten/kota, 7.000 kecamatan dan 77.000 kelurahan dan desa. Sebagian dari penduduk Indonesia tersebar di 39 kabupaten/kota, 13 provinsi perbatasan negara yang berdomisili di 111 kecamatan kawasan perbatasan, yang berbatasan langsung dengan negara tetangga dan di sebagian 92 pulau-pulau kecil terluar.

Sedangkan apabila diterapkan di Kabupaten Indramayu belum mampu menerapkan Model Desentralisasi Asimetris ini, oleh karena Kabupaten Indramayu bukan kawasan perbatasan negara, lain halnya apabila dyterapkan di daerah kawasan perbatasan lain di Indonesia yang memiliki kawasan perbatasan dengan sepuluh negara, baik perbatasan darat maupun perbatasan laut.

Sebagai perbandingan, bahwa negara Indonesia sebagai negara kepulauan, memiliki batas wilayah negara di darat dengan wilayah negara Malaysia, Papua Nugini (PNG), dan Timor Leste, di laut berbatasan dengan wilayah negara Malaysia, PNG, Singapura dan Timor Leste. Disamping itu, Indonesia memiliki hak-hak berdaulat yang dikenal dengan hak atas wilayah yurisdiksi yang berbatasan dengan wilayah yurisdiksi Australia, Fillipina, India, Malaysia, PNG, Palau, Thailand, Timor Leste dan Vietnam.

Lebih lanjut Agung dan informan lain dari anggota DPRD Kabupaten Indramayu menambahkan bahwa sejak lima tahun terakhir, pemerintah telah berkomitmen untuk mempercepat pembangunan kawasan perbatasan negara, mengubah kawasan perbatasan 
negara dari beranda belakang menjadi beranda depan negara. Hal itu ditunjukkan dengan dibentuknya Badan Nasional Pengelola Perbatasan (BNPP) berdasarkan Peraturan Presiden (Perpres) Nomor 12 Tahun 2010, sebagai tindak lanjut amanat UndangUndang (UU) Nomor 43 Tahun 2008 tentang Wilayah Negara. Namun, dalam perjalannya, pemerintah mengakui, masih banyak hal yang perlu dilakukan guna mempercepat pembangunan di kawasan perbatasan negara tersebut.

"Kami akan membangun Indonesia dari pinggiran dengan memperkuat daerah-daerah dan desa dalam kerangka Negara Kesatuan. Kami akan meletakkan dasar-dasar bagi dimulainya desentralisasi asimetris. Kebijakan desentralisasi asimetris ini dimaksudkan untuk melindungi kepentingan nasional Indonesia di kawasan-kawasan perbatasan, memperkuat daya saing ekonomi Indonesia secara global, dan untuk membantu daerah-daerah yang kapasitas berpemerintahan belum cukup memadai dalam memberikan pelayanan publik..." Indonesia memiliki kawasan perbatasan dengan sepuluh negara, baik perbatasan darat maupun perbatasan laut. Sebagai negara kepulauan, Indonesia memiliki batas wilayah negara di darat dengan wilayah negara Malaysia, Papua Nugini (PNG), dan Timor Leste, di laut berbatasan dengan wilayah negara Malaysia, PNG, Singapura dan Timor Leste. Disamping itu, Indonesia memiliki hak-hak berdaulat yang dikenal dengan hak atas wilayah yurisdiksi yang berbatasan dengan wilayah yurisdiksi Australia, Fillipina, India, Malaysia, PNG, Palau, Thailand, Timor Leste dan Vietnam. Sejak lima tahun terakhir, pemerintah telah berkomitmen untuk mempercepat pembangunan kawasan perbatasan negara, mengubah kawasan perbatasan negara dari beranda belakang menjadi beranda depan negara. Hal itu ditunjukkan dengan dibentuknya Badan Nasional Pengelola Perbatasan (BNPP) berdasarkan Peraturan Presiden (Perpres) Nomor 12 Tahun 2010, sebagai tindak lanjut amanat UndangUndang (UU) Nomor 43 Tahun 2008 tentang Wilayah Negara. Namun, dalam perjalannya, pemerintah mengakui, masih banyak hal yang perlu dilakukan guna mempercepat pembangunan di kawasan perbatasan negara tersebut. "Kita pun menyadari bahwa masih banyak persoalan yang belum dapat terselesaikan dengan tuntas, dan masih banyak hal yang memerlukan penanganan secara lebih intensif," sumeber BNPP dalam Kompas.com, 2015)

BNPP sendiri telah melakukan identifikasi atas berbagai persoalan yang melilit batas wilayah negara dan kawasan perbatasan. Menganalisis berbagai isu strategis yang menonjol, menyusun sejumlah opsi penyelesaian berbagai persoalan dan penanganan isuisu strategis yang ada, serta merumuskan agenda-agenda prioritas dalam rangka pengelolaan perbatasan negara secara terintegrasi, sinergis, dan terkoordinasi. Menteri Dalam Negeri (Mendagri) Tjahjo Kumolo selaku Kepala BNPP mengatakan, pemerintahan Jokowi-JK tetap berkomitmen untuk mempercepat pembangunan di kawasan perbatasan negara. Oleh karena itu, di awal-awal masa Kabinet Kerja, ia telah menugaskan jajaran BNPP untuk segera turun ke seluruh kecamatan perbatasan negara (lokasi prioritas) guna menginventarisir berbagai kebutuhan mendesak pembangunan infrastruktur di kawasan perbatasan tersebut. Selain itu, ia memandang, perlu dilakukan upayaupaya sinergis guna meningkatkan kesejahteraan masyarakat di perbatasan. 
"Karena tidak mungkin daerah perbatasan hanya cukup jalan bagus, tapi bagaimana masyarakat di kawasan itu tingkat kesejahteraannya meningkat, jadi rasanya sulit kalau Kabupaten Indramayu menerapkan konsep Desentralisasi Asimetris untuk saat ini, kecuali beralih menjadi kawasan perkotaan saja terutama di Kecamatan Jatibarang, Kabupaten Indramayu.

Sebagai bahan rujukan, penulis menelusuri kebijakan pemerintah terutama di Kementerian Dalam Negeri. Menteri Dalam Negeri (Mendagri) Tjahjo Kumolo selaku Kepala BNPP (2015) mengatakan dalam Kompas.Com bahwa pemerintahan Jokowi-JK tetap berkomitmen untuk mempercepat pembangunan di kawasan perbatasan negara. Oleh karena itu, di awal-awal masa Kabinet Kerja, ia telah menugaskan jajaran BNPP untuk segera turun ke seluruh kecamatan perbatasan negara (lokasi prioritas) guna menginventarisir berbagai kebutuhan mendesak pembangunan infrastruktur di kawasan perbatasan tersebut. Selain itu, ia memandang, perlu dilakukan upayaupaya sinergis guna meningkatkan kesejahteraan masyarakat di perbatasan. "Karena tidak mungkin daerah perbatasan hanya cukup jalan bagus, tapi bagaimana masyarakat di kawasan itu tingkat kesejahteraannya meningkat," jelas Kepala BNPP. Lanjut Beliau sesuai dengan agenda kebijakan konsep Desentralisasi Asimetris.

\section{SIMPULAN}

Hasil Penelitian menunjukkan bahwa Pengembangan Model Desentralisasi Asimetris di Kabupaten Indramayu harus memenuhi kriteria sebagai berikut:

(1) Adanya rasionalisasi kewenangan, artinya banyak berdiri kokoh kelembagaan pemerintah daerah yang masing-masing memiliki wewenang secara konstitusional atau rule of government;

(2) Adanya deferensiasi struktur, maksudnya didalam tubuh setiap kewenangan kelembagaan pemerintah daerah terdapat bobot dan ruang lingkup otoritas yang tidak saling sikut, saling klaim, dan saling lempar tanggung jawab;

(3) Adanya perluasan peran serta komunikasi politik massa atau rule of law instrument dalam penyelenggaraan kekuasaan pemerintah daerah. Dalam hal ini peran politik massa secara aktif dan kritis terhadap landasan filosofis pemerintahan demokratis, yaitu: adanya akuntabilitas, partisipatif, kesepakatan, kesetaraan hak, check and ballance.

\section{SARAN}

Dalam penerapan model desentralisasi asimetris ini, seperti di Kabupaten Indramayu, sebaiknya ada perbedaan perlakuan (treatment) antara satu daerah dan daerah yang lain dengan mempertimbangkan keragaman potensi daerah. Hal ini akan membantu proses mobilisasi sumber daya daerah dan sumber daya pemerintah yang lebih efisien untuk meningkatkan masyarakat di daerah. Oleh karena, esensi desentralisasi dan otonomi daerah yang dibangun di Indonesia pasca reformasi diterapkan jenis-jenis otonomi yang ada di Indonesia (otonomi reguler dan otonomi khusus) yang menjadi bukti empiris yang bisa dijadikan dasar untuk pengadopsian konsep desentralisasi asimetris. 


\section{DAFTAR PUSTAKA}

\section{A. Buku/Jurnal}

Abdilla Fauzi Achmad, 2012, Tata kelola Bernegara dalam Perspektif Politik, Golden Terayon Press, Jakarta.

Abdul Gaffar Karim, 2003. Komplesitas Persoalan Otonomi daerah di Indonesia. Gadjah mada Universitas, Yogyakarta.

Alderfer. H.F, 1964. Local Government in Developing Countries, New York, Mc.Graw Hill.Amal,

Asropi, 2008, Jurnal Ilmu Administrasi, Gadjah mada Universitas, Yogyakarta.

Baldan, Ferry Mursyidan, 2007, Mozaik Komentar dan Pendapat Pondasi Menuju Perdamaian Abadi, Jakarta: Suara Bebas.

Barclay, DJ, Schalkwyk And Pauw, JC. 2011. The Relationship Between Strategic Planning And Budgeting Within The Mining Qualifications Authority in South Africa. South Africa.

Barry, BW. 1997. Strategic Planning Workbook for Nonprofit Organizations. Publisher: Amherst H. Wilder Foundation.

Beratha, I Nyoman, 1982, Desa : Mayarakat Desa dan Pembangunan Desa, Ghalia Indonesi, Jakarta.

Bergel, Egon Ernest, 1955, Urban Sociology, McGraw Hill Company inc, New York.

Brian C. Smith, 2012. Desentralisasi Dimensi teritorial Suatu Negara, MIPI.

Brownell, Peter and Mc. Innes Morris, 1986, Budgetary Participation Motivation and Manajerial Performance, The Accounting Review.

Burn, D, Hamleton, R. Hogget, P. 1994. The Politics of Desentralization Revitalizmg Local Democracy, Lonon. Macmillan.

Conyers, Diana, 1986, Decentralization and Development: a Framework for Analysis, Community Development Journal. (Vol.21, Number 2, April).
Cheema, G. Shabbir, Dennis A Rondenelli, 1983. Decentralization and Development, Policy Implementation in Developing Countries. Sage Publication, Beverly Hills/London/New Delhi.

Creswell, John W, 1994, Research Design : Qualitative \& Quantitative Approaches. California: Sage Publication, Inc.,.

Dunn, William N. 1995. Analisa Kebijaksanaan Publik: Kerangka Analisa dan Prosedur Perumusan Masalah. Yogyakarta: Hanindita Graha Widya.

Erliana Hasan, 2011. Filsafat Ilmu dan Metodelogi Penelitian Ilmu Pemerintahan, Galia Indonesia.

Ernita, Peni, 2010, Pengaruh Partisipasi Penganggaran dan Komunikasi Organisasi terhadap Kinerja Manajerial SKPD Pada Pemerintah Kabupaten Gayo Lues dengan Budaya Paternalistik Sebagai Variabel Moderating. Tesis S2 Program Pasca Sarjana Universitas Sumatera Utara, Medan.

Gulick, L. dan L. Urwick, eds. (1937eebook. Papers on the Science of Administration. New York: Institute of Public Administration, Columbia University.

Gunawan, 2003. Seri Hukum Bisnis. Jakarta: Raja Grafindo.

Habib, A., \& Sukmana, Oman. 2002. Model Interaksi Sosial dalam Lingkungan Bauran Etnis Arab-Jawa: Studi di Kampung Embong Arab, Kota Malang. Malang: Lemlit UMM.

Herman Finer, 2006. Theory and Practice of Modern Government, Hendry Holt and Company, New York.

Hoessein, Bhenyamin, 2002. Perubahan Model dan Bentuk Pemerintahan, Jakarta: Atmajaya.

Hutington, Samuel, 2011. The Class of Civilizations and The Remarking of World Order. Simon \& Schuster.

Ichlasul. 1992, Regional and Cetral Government in Indonesian Politics: West Sumtra and South Sulawesi 1949-1979, Gadjah Mada University Press. Yogyakarta. 
Ingraham, PW And A.E Donahue, 2000, Dissecting the Black Box Revisited:Characterizing

Government Management Capacity. In C. Heinrich and L Lynn (Eds) Governance and Performance: New Perspective. Washington DC: Georgetown University.

Irwanto. 1998. Focus Group Discussion :Suatu Pengantar Praktis. Jakarta : Pusat Kajian Pembangunan masyarakat - Unika Atmajaya.

Kaplan, Robert. S dan David P. Norton, 1996, The Balanced Scorecard: Translating Strategy into Action, Harvard Business School Press,

-----------, 2001, Strategy Focused Organization, Harvard Business School Press,

----------, 2008, The Executive Premium: Linking Strategy to Operations for Competitive Advantage, Harvard Business School Press.

Kausar, A.S. 2006. Budaya Patron-Klien Dalam Perilaku Birokrasi di Daerah. Stusi di Kabupaten Tulang Bawang Propinsi Lampung. Disertasi. Program Pascasarjana Universitas Padjajaran Bandung.

Kingsley, Thomas G., 1996. Perspectives on Devolution, Journal of The Amerocan Planning Association, Vol. 62 Autumn.

Koswara Kertapraja, 2012. Pemerintahan Daerah, Konfiguasi Politik Desentralisasi dan Otonomi Daerah dulu, Kini dan tantangan Globalisasi. Inner.

Lemieux, Johanne, 1988. Le pouvoir et 'lappartenance: Une approche. Quebecamer.

Paul Du Gay, The Values of Bureaucracy, Oxford Unoversity Press.

Pamudji, $1984 . \quad$ Kepemimpinan Pemerintahan di Indonesia, Jakarta: Bumi Aksara.

Pearce II, John A. dan Richard B. Robinsonm, Jr., 2007, Manajemen Strategis Formulasi, Implementasi, dan Pengendalian. Jakarta: Salemba Empat.
Poister, Theodore H. And Streib, Gregory D., 1999, Strategic Management in the Public Sector: Concepts, Models and Processes. Public Productivity \& Management Review.

Pollit, C. and G. Bouckaert. 2000. Public Management Reform: Comparative Analysis. Oxford: Oxford University Press.

Maksum, Muhammad Syukron, 2012. Pengantar Filsafat. SCOOP Indonesia.

McGarry, Katie, 2007. Breaking the Rule. De Agostini.

Moleong, Lexy J. 1998. Metode Penelitian Kualitatif. Bandung: Remaja Rosdakarya.

M. A. Muttalib \& Mohd. Akbar Ali Khan, 2013, Theory of Local Government (Teori Pemerintahan Daerah), The Indonesian Society of Government Studies.

Marpaung, Andy Ramses, Politik Desentralisasi dan Desentralisasi Asimetris

---------. 2011, Perubahan Model, Pola dan Bentuk Pemerintahan Daerah :

Dari Era Orde Baru ke Era Reformasi, Jakarta : Departemen IlmU Administrasi, FISIP-UI, Edisi Revisi.

Millan, James and Sally Schumacher, 2015. Research in Education. Virginia Commanweei University.

Mowhood, Philip, 1987. Local Government in the Third World. New York: John Wiley \& Son.

Ndraha, Taliziduhu, 1991, DimensiDimensi Pemerintahan Desa, Bumi Aksara, Jakarta.

Nutt, PC and Backoff, RW., 1992, Strategic Management Of Public And Third Sector Organizations. New York.

Nyoman Sumaryadi, 2006. Otonomi Daerah Khusus dan Birokrasi Pemerintahan. LPMPI, Jakarta.

Pratikno, dkk, 2010, Desentralisasi Asimetris di Indoenesia : Praktek dan Proyeksi, Jurusan Politik dan Pemerintahan, JPP Fisipol-UGM dan Yayasan Tifa.

Purba, Jonny. 2002. Pengelolaan Lingkungan Sosial. Jakarta: Yayasan Obor Indonesia. 
Sanapiah Faisal. 2001. Format-Format Penelitian Sosial. Jakarta : Raja Grafindo Persada.

Sarwono, Sarlito, W. 1995. Psikologi Lingkungan. Jakarta: Gramedia.

Smith, Adam, 2001. Juctice and Police Revenue. Philadelphia.

Singarimbun, Masri, \& Sofian Effendi (ed.). 1995. Metode Penelitian Survey. Jakarta : LP3ES.

Sukmana, Oman. 2005. Pengaruh Kepadatan Sosial dan Persepsi tentang Lingkungan Sosial daerah Kumuh Perkotaan terhadap Perilaku Agresif Remaja. Jurnal Psikodinamik, Volume 7, No. 1 Januari 2005, ISSN 1411-3929. Malang: Fakultas Psikologi UMM.

Sukmana, Oman. 2003. Dasar-Dasar Psikologi Lingkungan. Malang: Bayu Media.

Soerjono Soekamto. 1986. Sosiologi : Suatu Pengantar. Jakarta : Rajawali Press.

Soemarwoto, Otto. 1997. Analisis Mengenai Dampak Lingkungan. Yogyakarta: Gadjah Mada University Press.

Tjokroamidjojo, $1987 . \quad$ Pengantar Administrasi Pembangunan. Jakarta: LP3ES.

Walgito, Bimo. 1994. Psikologi Sosial. Yogyakarta: Andi Offset.

Riyadi dan Bratakusumah, Deddy. 2004. Perencanaan Pembangunan Daerah: Strategi Menggali Potensi dalam Mewujudkan Otonomi Daerah. Gramedia Pustaka Utama. Jakarta.

Robert D. Lee, Jr., dan Ronald W. Johnson, 1977, Public Budgeting Systems, Edisi II, Baltimore: University Park Press

Rondinelli DA.,1983, Decentralization in Developing Countries, World Bank.

Ruiter, 1983. Manajer Tingkat Tengah. Jakarta: UI Press.

Salusu, J., 1996, Pengambilan Keputusan Strategik Untuk Organisasi Publik Dan Organisasi Non Profit". Jakarta: Grasindo.

Santoso, Priyo Budi. 1995. Birokrasi Pemerintah

Smith, B.C, 1985, Decentralization : The Territorial Dimension of The Stat,
Geroge Allen \& Unwin Publishers Ltd.

Suharto, Edi, 2007, Kebijakan Sosial Sebagai Kebijakan Publik, Penerbit Alfabeta.

Tillin, Louise, 2006, United in Diversity? Asymmetry in Indian Federalism, dalam Publiush : The Journal of Federalism, Volume 37 Number 1. Oxford University

Tjandra, Riawan, 2004. Hukum Administrasi Negara. Jakarta: Universitas Atmajaya.

UNDP, 2009. Human Development ReportThe Millenium Development Goals Report.

Vasu, M. L., D.W. Stewart dan G.D. Garson. (1998) Organizational Behavior and Public Management. New York: Marcel Dekker, Inc.

Wasistiono, Sadu, 2010, Desentralisasi dan Otonomi Daerah, IPDN. Jatinangor.

Wasistiono, Sadu, 2012, Kepemimpinan Pemerintahan, IPDN Jatinangor.

Wayne G. Bremser, 1995, Fundamentals of Budgeting for Nonfinancial Managers, American Management Association

Weber, Max. 1947. The Theory of Social and Economic Organization. Translated by A.M. Henderson and Talcot Parsons. New York: Oxford University Press.

Wasistiono, Sadu dan M. Irwan Tahir, 2006, Prospek Pengembangan Desa, Fokusmedia, Bandung

$\begin{array}{lrr}\text { Kawasan } & \text { Satinangor } & \text { Sebagai } \\ \text { Kawasan Perkotaan. } & \text { Laporan } \\ \text { Penelitian, Badan Perencanaan } & \text { Pembangunan Daerah. Sumedang : } \\ \text { Pemerintah Kabupaten Sumedang. }\end{array}$

Widodo, 2010. Good Governance, Telaah dari Dimensi Akuntabilitas dan Kontrol Birokrasi pada Era Desentralisasi dan Otonomi Daerah. Surabaya: Insan Cendekia.

B. Peraturan Perundang-undangan

Undang-Undang Nomor 23 Tahun 2014 tentang Pemerintahan Daerah; 
Undang-Undang Nomor 23 Tahun 2006 tentang Dinas Kependudukan dan Pencatatan Sipil;

Undang-Undang Nomor 25 Tahun 2004 tentang Sistem Perencanaan Pembangunan Nasional (Lembaran Negara Republik Indonesia Tahun 2004 Nomor 104, Tambahan Lembaran Negara Republik Indonesia Nomor 4421);

Undang-Undang Nomor 32 Tahun 2004 tentang Pemerintahan Daerah (Lembaran Negara Republik Indonesia Tahun 2004 Nomor 125, Tambahan Lembaran Negara Republik Indonesia Nomor 4437) sebagaimana telah diubah beberapa kali, terakhir dengan UndangUndang Nomor 12 Tahun 2008 tentang Perubahan Kedua Atas Undang-Undang Nomor 32 Tahun 2004 tentang Pemerintahan Daerah (Lembaran Negara Republik Indonesia Tahun 2008 Nomor 59, Tambahan Lembaran Negara Republik Indonesia Nomor 4844);

Undang-Undang Nomor 33 Tahun 2004 tentang Perimbangan KeuanganAntara Pemerintah Pusat Dan Pemerintahan Daerah (Lembaran Negara Republik Indonesia Tahun 2004 Nomor 126, Tambahan Lembaran Negara Republik Indonesia Nomor 4438);

Undang-Undang Nomor 39 Tahun 2008 tentang Kementerian Negara (Lembaran Negara Republik Indonesia Tahun 2008 Nomor 166, Tambahan Lembaran Negara Republik Indonesia Nomor 4916);

Undang-Undang Nomor 6 Tahun 2014 tentang Desa (Lembaran Negara Republik Indonesia Tahun 2014, Tambahan Lembaran Negara Republik Indonesia);

Peraturan Pemerintah Nomor 19 Tahun 2010 tentang Tata Cara Pelaksanaan
Tugas dan Wewenang serta Kedudukan Keuangan Gunawan. 2004. Pengaruh Reformasi Sistem Birokrasi Terhadap Pelaksanaan Otonomi Daerah di Kabupaten Kendari. Disertasi Program Pascasarjana Universitas Padjajaran, Bandung.

Peraturan Pemerintah Nomor 72 Tahun 2005 tentang Desa

Peraturan Pemerintah Republik Indonesia Nomor 6 Tahun 2008 Tentang Pedoman Evaluasi Penyelenggaraan Pemerintahan Daerah (Lembaran Negara Republik Indonesia Tahun 2008 Nomor 19, Tambahan Lembaran Negara Republik Indonesia Nomor 4815);

Peraturan Pemerintah Nomor 34 Tahun 2009 tentang Pedoman Pengelolaan Kawasan Perkotaan.

Peraturan Daerah Provinsi Jawa Barat Nomor 22 Tahun 2010 tentang Rencana Tata Ruang Wilayah Provinsi Jawa Barat Tahun 20092029.

Peraturan Daerah Nomor 49 Tahun 2014 tentang Nomenklatur, Jumlah, Susunan Organisasi dan Wilayah Kerja Unit Pelaksana Teknis Dinas dan Badan pada Satuan Kerja Perangkat Daerah Kabupaten Indramayu.

\section{Sumber Internet}

bappeda,indramayukab.go.id

kompas.com 2015

Muhadam Labolo, Derajat Desentralisasi Asimetrik Papua, makalah yang diunduh dari http://muhadamlabolo.blogspot.com/ 2013/08/derajat-desentralisasiasimetrik-papua.htm 